DOI: $10.2478 / \mathrm{sjdv}-2013-0009$

\title{
Etiology and pathogenesis of basal cell carcinoma
}

\author{
Željko P. MIJUŠKOVIĆ* \\ Department of Dermatology and Venereology, Faculty of Medicine, Military Medical Academy, University of defence, Belgrade, Serbia \\ *Corresponding author: Željko P. Mijušković, e-mail: mijuskovicz@orion.rs \\ DE GRUYTER
}

UDC 616.5-006.6-02:577.12

\begin{abstract}
Basal cell carcinoma (BCC) is the most common cancer among Caucasians. It generally occurs on sun-exposed areas of the body, mostly on the head and neck $(80 \%)$, trunk (15\%), rarely on arms and legs. Basal cell carcinoma is a good example of a disease caused by a combination of genetic and environmental factors. Ultraviolet (UV) radiation plays a dual role in the development of BCC: it causes DNA damage and immunosuppression. UVA and UVB rays damage the DNA via various mechanisms. UVB radiation directly damages DNA within skin cells, causing cytosine $\rightarrow$ thymine mutations at dipyrimidine sites, whereas UVA radiation is 10.000 times less mutagenic, but it is significantly more present in the natural UV radiation. Also, UVA photons have lower energy than UVB photons and do not induce mutations. UV radiation exerts immune suppression by decreasing the antigen presenting cells ability and by producing immunosuppressive cytokines, such as interleukin-10 (IL-10) and tumor necrosis factor alpha (TNF- $\alpha$ ). Mediators of UV-induced immunosuppression are DNA and cis-urocanic acid. Several studies showed a significant association between the development of BCC and sun-exposure during childhood and adolescence, and a strong relation with family history of skin cancer.

Exposure to ionizing radiation increases the risk of nonmelanoma skin cancers by three times, while the risk is proportional to the radiation dose.

Chemical carcinogens, such as arsenic, tar, psoralen, and pesticides, increase risks for nonmelanoma skin cancers, predominantly for squamous cell carcinoma (SCC).

Regarding genetic predisposition, there is glutathione S-transferase (GST) as an important part of cellular defense against endogenous and exogenous chemicals. Several polymorphisms in GST family members have been associated with impaired detoxification, thus influencing the risk for some cancers, including nonmelanoma skin cancers. Cytochrome P450 enzymes are involved in detoxification of photosensitizing agents, and thus involved in BCC carcinogenesis. PTCH is a tumor suppressor gene first identified in patients with Gorlin syndrome. Abnormal activation of this gene and its pathways result in various types of tumorigenesis. BCC is associated with homozygous PTCH gene deletion.

With regard to acquired genetic mutations, it was found that aggressive BCCs are significantly associated with increased p53 protein expression, probably representing the mutated form, although that assertion could not be established with certainty. Considering the apparently limited contribution of DNA damage and chromosome instability to the expression of BCC phenotype, the relevance of p53 mutations for BCC growth remains to be demonstrated. Data on the role of Bcl-2 gene family in the development of BCC are scarce. It is unclear whether Bcl-2 has a functional role in the development of BCC, or it only indicates the level of gene expression in tumor stem cells. Activation of Ras gene may play an important role during early stages in the development of nonmelanoma skin cancers, and it is often found on UV-exposed skin in BCC, actinic keratosis and SCC.

Concerning immunologic factors, studies have shown that tumor necrosis factor- $\alpha$ (TNF- $\alpha$ ) is the critical mast cell product involved in ultraviolet-induced immunosuppression: mast cells contain high quantities of TNF- $\alpha$ which is released after activation; the level of TNF- $\alpha$ is increased in the skin exposed to UV radiation disrupting the morphology and function of Langerhans cells, the principal antigen-presenting cells of the skin. An animal study suggests that the degree of susceptibility to ultraviolet-B-induced local immunosuppression depends on TNF- $\alpha$ level within the epidermis after UVB. It has been established that mast cell-derived histamine stimulates prostaglandin E2 (PGE2) production from keratinocytes. PGE2 alters the cytokine balance in favor of the immunosuppressive interleukin-10 (IL-10) against the immunostimulatory IL-12; histamine also increases suppressor T-cell function by binding to the $\mathrm{H} 2$ receptors, which in turn release higher levels of immune suppressive cytokines including IL-10 and induce apoptosis of antigen-presenting cells. All this results in a shift of the immune response from T helper 1 (Th1) cytokine profile to T helper 2 (Th2) cytokine profile, inhibiting antigen-presenting cells to induce antitumor activity.
\end{abstract}

\section{Key words}

Carcinoma, Basal Cell + etiology + pathology + genetics; Immunosuppression; Ultraviolet Rays; Risk Factors; Genes, Tumor Suppressor; Genes, p53; Genes, bcl-2 
$\mathrm{B}$ asal cell carcinoma (BCC) is the most common type of skin cancer in Caucasians. It mostly occurs in areas that are often exposed to the sun and is most frequently manifested on the head and neck (80\%), the trunk (15\%) and rarely on upper and lower extremities. Also, very rarely, BCC affects the skin on axillary and perineal region, the hands and soles and genital region $(1,2,3)$. Skin phototypes 1 and 2, male sex, old age and history of previous sun burns are all considered significant risk factors in developing BCC (1).

Also, simultaneous appearance of $\mathrm{BCC}$ and other cutaneous lesions, that come as a direct consequence of exposure to UV radiation and skin phototype, such as solar lentigo and actinic keratosis, has also been proven. Apart from standard sun-ptrotection, chemopreventive agents such as retinoids offer the possibility of effective non-melanoma skin cancer prevention (4).

Basal cell carcinoma is a good example of a disease caused by interaction of genetic and sitespecific factors. However, BCC remains a frequent challenge for dermatologists (5). The following text will explain factors that influence its development and pathogenesis.

\section{Ultraviolet Radiation}

Ultraviolet (UV) radiation plays two key roles in the development of BCC: it causes DNA damage and immunosuppression (6). UVA and UVB rays damage DNA by different mechanisms. UVB rays harm the DNA directly by causing constitutional cythosine à thymine ( $\mathrm{C}$ à $\mathrm{T})$ mutations at dyprimidine sites, as well as CC à TT, while UVA rays have 10.000 times lower mutagenic effect but are significantly more present in natural UV radiation (7). Also, UVA radiation photons are lower in energy compared to UVB radiation photons and have no mutagenic effect.

UVB radiation induces cutaneous ornithinedecarboxylase, the first enzyme in polyaminebiosynthesis pathway, which plays an important role in proliferation and monoclonal expansion of initially mutated cells leading to cancerogenesis. Grossman and Leffell demonstrated the association between exposure to UVB rays and skin cancer development (6). UV radiation induces immunosuppression by reducing antigen-presenting ability, as well as immunosuppressive cytokine production, such as interleukin-10 (IL-10) and tumor necrosis factor alpha (TNF-a) (1). Mediators of immunosuppression induced by UV radiation are DNA and cis-urocanic acid.

UV radiation-induced mutations of the human patched gene $(\mathrm{PTCH})$ were found in several sporadic cases of BCC, approximately $30-41 \%$ (8). However, this type of DNA damage has been recorded in $79 \%$ of patients suffering from BCC and xeroderma pigmentosum (9). Half of these cases had both PTCH and p53 mutations, as well as a large number of UV specific alterations (10). These results strongly suggest the existence of other causes of mutation, in adition to UV radiation, which can cause inactivation of PTCH and initiate tumorigenesis. This hypothesis is supported by results of epidemiological studies showing low correlation between the dose of UVB radiation and occurrence of $\mathrm{BCC}$, as opposed to higher correlation between UVB radiation and squamous cell carcinoma (SCC) (11). Vitasa et al. demonstrated that the cumulative dose of ultraviolet radiation is in direct correlation with occurrence of SCC, but not with occurrence of BCC (12). Considering the fact that BCC develops from cells found in deeper skin layers than SCC, it can be assumed that these two tumors need different doses and wavelenghts of UV rays in order to occur. Several studies indicate that short-term intermitent exposure to UV rays during vacations can pose a higher risk of skin cancer compared to the amount of sun exposure that outdoor workers get (13). Corona et al. noted a significant association between occurrence of BCC and sun exposure during childhood and adolescence, as well as its high correlation with family history of skin cancer (14). Ramani and Bennett reported a significantly higher incidence of BCC in Second World War soldiers based in the Pacific as opposed to those who were stationed in Europe (15). These data show that intense UV exposure in periods ranging from a few months to several years can have long-term harmful effects. In adition, latitude plays no important role in development of BCC, which is not the case with SCC (16). Regular use of sunscreens before the age of eighteen, reduces the risk of nonmelanoma skin cancers by up to $78 \%$ (17).

Several studies show an increased risk of BCC and SCC in people who are exposed to artificial sources of 
UV radiation $(18,19)$. Thus, when it comes to BCC, Boyd et al. determined that female patients with BCC visited solariums twice as much than patients in the contol group (20). However, a significant number of BCC cases develop on skin that has not been exposed to UV rays, e.g., recently Popadić et al. reported a patient who exhibited superficial BCC on the penis (3), suggesting the existence of other risk factors that contribute to the occurrence of BCC.

\section{Ionizing Radiation}

Exposure to ionizing radiation increases the risk of nonmelanoma skin cancers by three times (17). The risk is proportional to the amount of recieved radiation. It is generally believed that high single doses of radiation (> 12-15 Gy) are required for the tumor to develop, which means the risk caused by ionizing radiation can be reduced if the total radiation sum is fractioned into smaller individual doses (21). Most SCC and BCC cases that occur due to ionizing radiation have a long latency period, lasting up to a few decades. Before the discovery of effective antifungal medications, treatment of fungal scalp infections was associated with the development of multiple BCCs. In a study including 2.224 Caucasian children treated with X-rays, the relative risk of developing BCC on the head and neck proved to be higher [RR $3.6(95 \%$ CI, 2.3-5.9)], compared to the control group of 1.380 children treated only with topical therapy (22). Cases of BCC on skin within the radiation field after therapy for port wine stain vascular malformation, Hodgkin disease, as well as after accidental radiation, have all been documented (23).

\section{Chemical Carcinogens}

Chemical carcinogens, such as arsenic, tar, psoralens and pesticides increase the risk of nonmelanoma skin cancers, predominantly SCC. Lesions are mainly localized on the hands and are usually multiple (24). The period from exposure to chemical carcinogens and the occurrence of tumors lasts from 20 to 40 years (25). Exposure to psoralen combined with UVA radiation (PUVA), used in the treatment of patients with psoriasis, increases the risk of BCC and SCC. However, some studies show no increased risk of BCC in patients undergoing PUVA therapy (26). Considering all facts, it can be concluded that agents causing DNA damage more often lead to the development of SCC than BCC. This observation is consistent with the fact that in congenital diseases, caused by defects in DNA reparation process, the above mentioned defects are more often manifested with SCC than with BCC.

\section{Viruses}

Some authors point to the connection of oncogenic types of human papillomaviruses (HPV) and the development of BCC $(27,28)$. HPV-DNA has been detected in $\mathrm{BCC}$ related lesions, indicating a possible role of HPV infections in the development of BCC $(27,28)$. It is generally assumed that carcinogenesis is associated with apoptosis inhibition, by blocking the effects of $\mathrm{Bcl}-2$ homologous antagonist killer protein by the HPV E6 protein. However, a strong correlation between HPV and BCC has not yet been established, and there is a reasonable doubt that this correlation will ever be confirmed (29).

\section{Genetic Predisposition}

\section{Glutathion S-transferase}

Glutathion S-transferase (GST) is part of the cellular defense mechanism against chemicals, endogenous or exogenous: UV radiation causes oxidative stress in skin cells, leading to lipid peroxidation and DNA damage via hydrogen formation. GST is responsible for removing these potential mutagens. Seven distinct gene families are responsible for coding human soluble GST synthesis. Most of the genes belonging to these families are polymorphic, but researchers most frequently concentrate on mi, theta and $p i$ gene families. Alpha, $m i$ and $p i$ classes counteract potentially dangerous $a$ - $\beta$-unsaturated carbonyl compounds, such as acrolein found in cigarette smoke, 4-hydroxynonenal, adenine- and thyminepropene caused by the oxidative DNA damage, and aminochrome, dopachrome and noradrenochrome which are derived from catecholamine (30). Zeta class enzymes degrade dichloroacetic acid, a common contaminant in chlorinated drinking water (30). Unlike other classes, theta class enzymes catalyze a number of important small dihaloalkanes, such as dichloromethane used in chemical synthesis of plastic and drug manufacturing (30). In addition, theta class enzymes metabolize: monochlorometane, ethylene 
oxid present in cigarette smoke, and polycyclic aromatic hydrocarbon epoxides (30). GST activity is mostly expressed in sebaceous glands and outer hair follicle sheath. Insufficient detoxification of some polymorphic GST family members increases the risk of cancer, including nonmelanoma skin cancers. GSTT1 null genotype is associated with high sensitivity to UV radiation. GSTM1 null genotype is also associated with predisposition to BCC, most probably due to its role in defense mechanisms against UV-induced oxidative stress $(29,31)$. It has been proved that GSTM3 polymorphism also increases the risk in BCC occurrence (32).

\section{Cytochrome P450}

Cytochrome P450 enzymes (CYP) are a superfamily of monooxygenases that catalyze the oxidation of various organic substances. These enzymes are part of the detoxification process of photosensitive agents, and therefore are also included in BCC carcinogenesis: genetic polymorphism CYP2D6 (cytochrome P450 encoding gene) correlates with an elevated number of BCC (33). In addition, certain CYP2D6 allelic variants are in direct correlation with the occurrence of multiple BCCs. Patients who carry them have an elevated risk of developing BCC in the future (34).

\section{DNA Repair}

It has been observed, in 1973, that patients suffering from xeroderma pigmentosum are prone to SCC, BCC and melanoma $(29,35)$. Segerbäck et al. demonstrated that BCC patients have a less efficient DNA repair mechanism compared to healthy individuals (36). Werner and Bloom syndrome are hereditary diseases associated with DNA helix defects and a high tendency to develop skin cancer, but not $\mathrm{BCC}(37,38)$. Contrary to these, patients with Rothmund-Thomson syndrome do develop BCC, considering that DNA helix defects are present only in some cases. Diseases identified with chromosome instability, such as ataxia-telangiectasia syndrome and Nijmegen breakage syndrome, do not carry an increased risk of BCC. The same goes for Li-Fraumeni syndrome, which may be caused by $\mathrm{p} 53$ gene mutations, and dyskeratosis congenital, associated with defect in telomere maintenance $(29,39,40)$. The reason for which various forms of genetic instability are not associated with the development of BCC is unknown. Biological differences between BCC and other malignancies may be one explanation: primarily due to the fact that most tumors, sooner or later, show chromosomal instability, which does not seem to be the case with BCC (29).

\section{Patched Gene}

The patched gene $(\mathrm{PTCH})$ is a tumour-suppressor gene first discovered in patients suffering from Gorlin syndrome. PTCH inactivation in people with Gorlin syndrome raised suspicion that $\mathrm{PTCH}$ mutations can also contribute to the pathogenesis of sporadic BCC. Alternations in PTCH have been detected in $30-40 \%$ of sporadic BCC cases, $41 \%$ of which carry specific UV-signature mutations: C-T, CC-TT substitutions at dypirimidine sites, suggesting that UVB rays play a role in their development. All BCC lesions carrying this type of mutation occur on skin that has been exposed to UV radiation, which further confirms these claims (41). The gen is located in the 9q22.3 chromosome and regulates the process of gene expression, thus controlling embryonic cell development, growth and differentiation processes, such as Hedgehog signaling pathway. Abnormalities in the activation of $\mathrm{PTCH}$ and its signaling pathways lead to various types of carcinogenesis: homozygous deletion of the patched gene is necessary for the formation of BCC. Earlier studies demonstrate the occurrence of $\mathrm{BCC}$ in patched heterozygous mutant mice, but for the occurrence of these tumors UV or ionizing radiation is necessary and, in some cases, p53 mutations as well (42). The PTCH gene is responsible for coding the synthesis of a large transmembrane glycoprotein that, combined with a transmembrane glycoprotein coded by the Smo gene (smoothened gene), forms a part of the receptor complex. This protein complex is the principal receptor for the hedgehog extracellular signaling molecule. The patched gene protein acts as a Smo inhibitor. Abnormal activation of the Smo protein leads to continuous uncontrolled signal transmission to the nucleus, resulting in the transcription activation controlled by the so called Gli transcription factors. PTCH mutations cause inactivation of the suppression function and lead to uncontrolled cell proliferation, resulting in tumor formation. PTCH damage causes not only changes in the hedgehog signaling pathway 
but also in downstream events. This mainly refers to the Wnt gene and its protein product. Certain genetic polymorphisms are associated with certain phenotypic characteristics of BCC. PTCH mutations are found in all types of BCC, but their expression levels do not correlate with different types of tumors (43).

In addition to PTCH mutations, sporadic BCC cases also contain Smo gene mutations (6-20\%) as well as PTCH2 mutations. The highest percentage of Smo gene mutations were detected in BCC lesions in patients with xeroderma pigmentosum. All this points to the fact that mutations in one (or more) signaling pathway components inevitably lead to uncontrolled cell proliferation, which ultimately results in tumor occurrence.

\section{Nuclear factor kappa-light-chain- enhancer of activated $B$ cells (NF- $\kappa B$ )}

A good example of the importance of embryonic developmental pathway in occurrence of BCC is the discovery that deficiency in nuclear factor kappa-

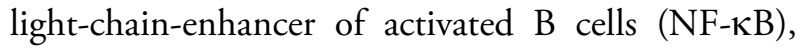
one of the signal pathway components, can also cause BCC (29).

The activation of NF-kB depends on phosphorylation and subsequent degradation of NF-kB inhibitor proteins (IkB) via IkB kinase complex (100). The NEMO gene (nuclear factor $B$ essential modulator) mutation which causes incontinentia pigmenti, is part of the IkB kinase complex. In adition, cylindromatosis (CYLD) gene intarracts with the NEMO gene, and these mutations were found with the familiar trichoepithelioma (44, 45). These findings suggest that the NF-kB singnaling pathway, involved in inflammatory processes and embryogenesis of skin adnexal epithelium, may also affect the development of BCC (29).

\section{Acquired Genetic Mutations}

\section{p53 gene}

Most common genetic aberrations in skin carcinomas, as well as their precursor lesions, are found in the $\mathrm{p} 53$ gene (46). The p53 gene is responsible for coding the synthesis of phosphoprotein and is part of the cell cycle system and enables chromosome stability. In case of cellular stress, i.e. DNA damage, p53 is activated by phosphorylation. The level of $\mathrm{p} 53$ protein in the cell determines the cellular reaction to existing DNA damage: in case of low or medium $\mathrm{p} 53$ expression, the cell will allow DNA repair, but high p53 levels result in cellular apoptosis (47). The so called wild type p53 is not detectable in healthy skin, but becomes visible two hours after sun exposure. Its levels peak after 24 hours, only to become undetectable 36 hours after radiation exposure (48). Mutated p53 gene is known to accumulate inside the cell, and these mutations have been detected in approximately half of all BCC patients (49). Also, it has been suggested that more aggressive types of $\mathrm{BCC}$ go hand in hand with elevated p53 expression, probably in its mutated form, but this claim has not been proven yet (29). Consequently, it seems reasonable to assume that $\mathrm{p} 53$ mutations are secondary events in BCC pathogenesis occurring after tumor initiation. The vast majority of $\mathrm{p} 53$ mutations in sporadic BCCs are missense mutations, frequently displaying UV-signature. In patients with Gorlin syndrome, p53 gene mutations are different, showing single nucleotide deletions, previously undetected in sporadic BCC, SCC or actinic keratosis, as well as rare double substitution of base pairs. One possible explanation could be that patients with Gorlin syndrome avoid solar radiation due to propensity for skin cancer, and that several mutations are secondary to other mutagenic events such as oxidative stress.

A study including BCC patients, compared those who used sunscreens and those who did not, showed a significantly lower level of p53 gene mutations in patients using UV protection, which supports the assumption that mutations of $\mathrm{p} 53$ gene are secondary events that may not contribute considerably to tumorigenesis (50). Other studies showed that p53 mutations were detected in 33\% of BCCs found in Korean patients compared to $50 \%$ of BCCs in Caucasian patients $(49,51)$. These findings suggest that ethnic factors play an important role in the development of BCC, as well as life-style habits related to UV exposure. Due to the limited role of DNA damage and chromosomal instability in the development of $\mathrm{BCC}$, the role of $\mathrm{p} 53$ gene mutations in BCC remains unclarified (29).

Finally, in the absence of genetic damage, p53 activation will not occur. Moreover, one of the hallmarks of p53 dysfunction, aberrant mitosis, perhaps as a consequence of centrosome amplification, has never been observed in BCC (52). 


\section{p63 gene}

The p63 gene, a p53 homologue and a member of the p53 family of proto-oncogenes, is located on chromosome $3 \mathrm{q} 27$ and encodes at least six different protein isoforms. The p63 is restricted to cells with a high proliferative potential, and is absent in cells undergoing terminal differentiation. The p63 gene is rarely mutated in BCC. It was shown that aberrant expression of p63 altered the UVB-induced apoptotic pathway, suggesting that down-regulation of this protein in response to UV radiation is important in epidermal apoptosis (53).

\section{Bcl-2 gene}

The $\mathrm{Bcl}-2$ gene encodes synthesis of $\mathrm{Bcl}-2$ protein expressing $24 \mathrm{kDa}$ anti-apoptotic protein previously identified in human B-cell lymphoma. The cytoarchitectural distribution of $\mathrm{Bcl}-2$ protein in normal skin includes basal keratinocytes, the dermal papillae of the hair follicle, the keratinized Huxley's and Henle's layers, and the keratinized outer root sheath cells of the isthmus and infundibulum of the hair follicle. Bcl-2 expression is negative in suprabasal keratinocytes (54). Most BCCs, if not all, express high levels of Bcl-2 protein, whereas SCCs typically exhibit no detectable BCL-2 protein $(55,56)$. In comparison with invasive BCCs, high level of $\mathrm{Bcl}-2$ was found in less aggressive types of BCCs. There are some studies which stated that Bcl-2 diffusely stains the tumor nests in BCCs, while it stains the outermost cell layers in trichoepithelioma (56).

Another member of Bcl-2 family, the so-called BAX gene, encodes the synthesis of BAX protein with pro-apoptotic properties which is not elevated in BCC (57). Data on the role of other Bcl-2 family members in the development of BCC are scarce. It is an interesting paradox that BCC, with high level of apoptosis, expresses anti-apoptotic proteins (42). In the end, it is unclear whether $\mathrm{Bcl}-2$ has a functional role in the development of $\mathrm{BCC}$, or it only indicates the level of gene expression in tumor stem cells.

\section{Ras genes}

Ras genes are important constituents of mitogenic signaling pathways, and when activated, they contribute to deregulated cellular growth. The activated Ras genes can play an important role during early stages in the development of nonmelanoma skin cancers, and it is often found on UV exposed skin in BCC, actinic keratosis and SCC. The activation of Ras genes is a result of aberrant repair of UV-induced pyramidine dimers.

\section{Matrix metalloproteinases}

Matrix metalloproteinases (MMPs) are a family of zinc dependent endopeptidases that degrade the extracellular matrix. Matrix metalloproteinases are produced by cells such as fibroblasts, keratinocytes, macrophages, endothelial cells, mast cells, and eosinophils. The activity of MMPs is inhibited by tissue inhibitors of metalloproteinases binding with active MMPs. Most MMPs are not expressed in normal intact skin, but they may temporarily be induced as a response to exogenous signals such as UV radiation. Aggressive types of BCCs express MMPs.

\section{Immunologic factors}

\section{Immunosuppression}

Organ transplant recipients are at higher risk for developing cancer because they often require lifelong immunosuppressive therapy. Malignancies occur in at least $20 \%$ of transplant recipients within 20 years after grafting. Among them, skin carcinomas account for up to $50 \%$ (58). SCC of the skin is the most common malignancy occurring in the setting of solid-organ transplantation and immunosuppression, and its incidence increases substantially with extended survival after transplantation. Increased incidence of BCC has not been described in organ recipients, so it seems clear that immunosuppressive therapy after organ transplantation does not increase the risk of developing BCC (29). In a study involving South Australian and Danish subjects, patients with a history of basal cell carcinoma and melanoma are found to have a significantly higher, genetically predetermined density of dermal mast cells $(59,60)$. It is suggested that a higher density of dermal mast cells is a predisposing factor for the development of $\mathrm{BCC}$ and melanoma, and predisposes an individual to ultraviolet-B-induced immunosuppression. However, a similar correlation has not been found for patients with SCC, probably because development of SCC is caused by other immunomodulatory mechanisms (61).

Tumor necrosis factor- $\alpha$ (TNF- $\alpha$ ) is the critical mast cell product involved in ultraviolet- 
induced immunosuppression: mast cells contain high quantities of TNF- $\alpha$ which is released after activation; the level of TNF- $\alpha$ is increased in the skin exposed to UV radiation disrupting the morphology and function of Langerhans cells, the principal antigenpresenting cells of the skin. An animal study suggests that the degree of susceptibility to ultraviolet-Binduced local immunosuppression depends on TNF- $\alpha$ levels within the epidermis after UVB (62). Mast cell-derived histamine stimulates prostaglandin E2 (PGE2) production from keratinocytes. PGE2 alters the cytokine balance in favor of the immune suppressant interleukin-10 (IL-10) against the immunostimulatory IL-12 (63); histamine also increases suppressor T-cell function by binding to the $\mathrm{H} 2$ receptors, which in turn release higher levels of immune suppressive cytokines including IL-10 and induce apoptosis of antigen-presenting cells (64).

Several studies have shown that the level of immunosuppression is dose-dependent on UV irradiation, whereas immunosuppression is mediated by T-lymphocytes $(65,66)$. The mechanism of immunosuppression is based on two chromophores: DNA and urocanic acid, both altering expression of the following cytokines: TNF- $\alpha$, IL- $1 \alpha / \beta$, IL-3, IL-6, IL-8, IL-10, granulocyte-macrophage colony stimulating factor (GM-CSF) and nerve growth factor (NGF) (67). All this results in a shift of the immune response from $\mathrm{T}$ helper 1 (Th1) cytokine profile to T helper 2 (Th2) cytokine profile, inhibiting antigenpresenting cells to induce antitumor activity $(67,68)$. It is assumed that production of IL-10 by keratinocytes or tumor cells induces immunosuppression and antiinflammatory effects providing tumor cells to avoid immune response. It has been observed that most patients with solid tumors have increased levels of IL-10 (69). All these data show that UV radiation compromises the immune system of patients with cutaneous tumors (68).

\section{Human Immunodeficiency Virus}

Seemingly in contradiction to the lack of an increase in the incidence of BCC in organ recipients, people suffering from acquired immune deficiency syndrome (AIDS) have shown an elevated risk for developing BCC (70). There have also been some reports of BCCs metastasizing in people suffering from AIDS, suggesting that immune surveillance is one of the factors determining the normally nonmetastatic nature of the BCC (71). Why immunosuppression by HIV increases the risk of $\mathrm{BCC}$, whereas pharmaceutical immunosuppression in transplant recipients does not, is not clear.

\section{Human Leukocyte Antigen (HLA)}

The major histocompatibility complex (MHC) genes code for membrane proteins that play important roles in controlling immune responses. While normal skin lesions show high levels of class I molecules (MHC I), BCC shows either complete absence or heterogeneous expression (72). All class I-negative tumors were histologically proven to be aggressive, whereas all nonaggressive BCCs were class I-positive. Low levels or absence of expression of class I antigens may result in escape from regulation by cytotoxic $T$ cells, which then facilitates tumor growth (73). Evidence for the involvement of HLA genes in the development of skin cancers was provided by Bouwes Bavinck et al. These authors showed that the presence of HLA-DR7 and a decrease of HLA-DR4 are significantly associated with BCC (74). This corroborates the previous finding of Rompel et al. that HLA-DR4 is decreased in BCC, especially in patients with multiple BCCs located on the trunk. The authors suggested a protective role for HLA-DR4 against the development of BCC (75, 76). Czarnecki and associates showed that HLA-DR1 antigen is weakly associated with the development of multiple BCCs at an early age (77).

\section{Cancer Stem Cells}

The cellular origin of BCC is considerably less defined than in SCC. Several cell types have been suggested to be the precursor cells or stem cells for BCC: interfollicular basal keratinocytes, basal keratinocytes from hair follicles or sebaceous gland cells $(78,79)$. In general, stem cells have a relatively undifferentiated and slow-cycling phenotype, but can be stimulated to proliferate and give rise to transient amplifying cells which have a limited proliferative potential (80). Stem cells may be the target of carcinogens and as such play an important role in tumorigenesis. As first suggested, stem cells in the skin are in the bulge region of the outer root sheath (81). In support of this hypothesis, chemically-induced BCCs in rats arise from hair follicles, but it is not known whether this is also the case in humans. As a result, hair 
follicles are likely to play an important role in skin homeostasis, wound healing and tumorigenesis (80). Histologically, BCC may resemble hair follicles, and may show characteristics from both bulge region stem cells and transient amplifying cells (82). In particular, BCC can histologically resemble trichoepithelioma, a benign hair follicle tumor (83). The suprabulbar region of the outer root sheath of the hair follicle has an immunohistochemical profile that is almost indistinguishable from that of a BCC (84). The hair follicle hypothesis is further supported by the fact that when a carcinogen is added in the anagen phase, in which the hair follicle bulge region cells undergo transient amplification, BCCs are generated more frequently (85). Furthermore, BCCs seldom occur on non-hairy skin, whereas expression of the basal cell adhesion molecule (B-CAM) occurs both in normal and diseased skin $(82,86)$. This cell-surface protein is preferentially expressed in suprabasal cell layers and the outer root sheaths of the hair follicle. It also shows high levels of expression in BCCs, suggesting that BCCs originate from hair follicles rather than from basal keratinocytes, which are negative for B-CAM in normal skin (29). However, the lack of cytokeratin 15 expression in the tumor cells supports the hypothesis that BCCs do not differentiate towards a hair bulge cell fate (87).

Finally, in conclusion, results of previous studies indicate that the hair follicle stem cell is the progenitor cell of the BCC. It seems that BCC cell is a hair follicle stem cell in which the normal differentiation and anagen-initiation program has gone awry (29). Unfortunatelly, the biomolecular basis responsible for the different susceptibility of skin at different sites of the body to BCC development is still not known (88).

\section{References}

1. Mithoefer AB, Supran S, Freeman RB. Risk factors associated with the development of skin cancer after liver transplantation. Liver Transpl 2002;8:939-44.

2. Al Junidi KF, Paravina M, Katić V, Mitsa P. Basal cell carcinoma: a retrospective clinicopathological analysis of 100 cases derived from the histopathological registry of the Institute of pathology in Niš. Serb J Dermatol Venereol 2012;4(1):18-30.

3. Popadić S, Tanasilović S, Živanović D, Medenica Lj. Genital superficial basal cell carcinoma: a case report. Serb J Dermatol Venereol 2010;2(3):106-9.

4. Prado R, Francis SO, Mason MN, Wing G, Gamble RG, Dellavalle R. Nonmelanoma skin cancer chemoprevention. Dermatol Surg 2011;37(11):1566-78.
5. Roš T, Gajić B, Rajić N, Ivkov-Simić M, Gajinov Z. Basal cell carcinoma: a frequent challenge. Serb J Dermatol Venereol 2012;4(1):5-17.

6. Grossman D, Leffell DJ. The molecular basis of nonmelanoma skin cancer: new understanding. Arch Dermatol 1997; 133:1263-70.

7. Tran H, Chen K, Shumack S. Epidemiology and aetiology of basal cell carcinoma. Br J Dermatol 2003;149(Suppl 66):50-2.

8. De Gruijl FR, Van Kranen HJ, Mullenders LH. UV-induces DNA damage, repair, mutations and oncogenic pathways in skin cancer. J Photochem Photobiol 2001;63:19-27.

9. Holíková Z, Massi D, Lotti T, Hercogová J. Insight into the pathogenesis of sporadic basal cell carcinoma. Int J Dermatol 2004;43:865-9.

10. Bodak N, Queille S, Avril MF, Bouadjar B, Drougard C, Sarasin A, et al. High levels of patched gene mutations in basal cell carcinomas from patients with xeroderma pigmentosum. Proc Natl Acad Sci USA 1999;9:5117-22.

11. Soehnge H, Ouhtit A, Ananthaswamy ON. Mechanisms of induction of skin cancer by UV radiation. Front Biosci 1997;2:538-51.

12. Vitasa BC, Taylor HR, Strickland PT, Rosenthal FS, West S, Abbey $\mathrm{H}$, et al. Association of nonmelanoma skin cancer and actinic keratosis with cumulative solar ultraviolet exposure in Maryland watermen. Cancer 1990;65:2811-7.

13. Rigel DS, Friedman RJ, Kopf AW. Lifetime risk for development of skin cancer in the U.S. population: current estimate is now 1 in 5. J Am Acad Dermatol 1996;35:1012-3.

14. Corona R, Dogliotti E, D’Errico M, Sera F, Iavarone I, Baliva $\mathrm{G}$, et al. Risk factors for basal cell carcinoma in a Mediterranean population: role of recreational sun exposure early in life. Arch Dermatol 2001;137:1162-8.

15. Ramani ML, Bennett RG. High prevalence of skin cancer in World War II servicemen stationed in the Pacific theater. J Am Acad Dermatol 1993;28(5 Pt 1):733-7.

16. Marks R. An overview of skin cancers: incidence and causation. Cancer 1995;75(2 Suppl): 607-12.

17. Stern RS, Weinstein MC, Baker SG. Risk reduction for nonmelanoma skin cancer with childhood sunscreen use. Arch Dermatol 1986;122:537-45.

18. Hemminki K, Zhang H, Czene K. Time trends and familial risks in squamous cell carcinoma of the skin. Arch Dermatol 2003;139:885-9.

19. Karagas MR, Stannard VA, Mott LA, Slattery MJ, Spencer SK, Weinstock MA. Use of tanning devices and risk of basal cell and squamous cell skin cancers. J Natl Cancer Inst 2002;94:224-6.

20. Boyd AS, Shyr Y, King LE Jr. Basal cell carcinoma in young women: an evaluation of the association of tanning bed use and smoking. J Am Acad Dermatol 2002;46:706-9.

21. Lichter MD, Karagas MR, Mott LA, Spencer SK, Stukel TA, Greenberg ER. Therapeutic ionizing radiation and the incidence of basal cell carcinoma and squamous cell carcinoma The New Hampshire Skin Cancer Study Group. Arch Dermatol 2000;136:1007-11.

22. Shore RE, Moseson M, Xue X, Tse Y, Harley N, Pasternack BS. Skin cancer after X-ray treatment for scalp ringworm. Radiat Res 2002;157:410-8.

23. Stante M, Salvini C, De Giorgi V, Carli P. Multiple synchronous 
pigmented basal cell carcinomas following radiotherapy for Hodgkin's disease. Int J Dermatol 2002;41:208-11.

24. Lei U, Masmas TN, Frentz G. Occupational non-melanoma skin cancer. Acta Dermatol Venereol 2001;81:415-7.

25. Wong SS, Tan KC, Goh CL. Cutaneous manifestations of chronic arsenicism: review of seventeen cases. J Am Acad Dermatol 1998;38(2 PT 1):179-85.

26. Stern RS, Laird N. The carcinogenic risk of treatments for severe psoriasis. Photochemotherapy follow-up study. Cancer 1994;73:2759-64.

27. Barr BB, Benton EC, McLaren K, Smith IW, Bunney MH, Smith IW, et al. Human papilloma virus infection and skin cancer in renal allograft recipients. Lancet 1989;1:124-9.

28. Weinstock MA, Coulter S, Bates J, Bogaars HA, Larson PL, Burmer GC. Human papillomavirus and widespread cutaneous carcinoma after PUVA photochemotherapy. Arch Dermatol 1995;131:701-4.

29. Tilli CMLJ, Van Steensel MA, Krekels GAM, Neumann HAM, Ramaekers FCS. Molecular aetiology and pathogenesis of basal cell carcinoma. Br J Dermatol 2005;152:1108-24.

30. Hayes JD, Strange RC. Glutathione S-transferase polymorphisms and their biological consequences. Pharmacology 2000;61:154-66.

31. Lear JT, Strange RC, Fryer AA. Relationship between sunlight exposure and a key genetic alteration in basal cell carcinoma. J Natl Cancer Inst 1997;89:454-5.

32. Yengi L, Inskip A, Gilford J, Alldersea J, Bailey L, Smith A, et al. Polymorphism at the glutathione transferase locus GSTM3: interactions with cytochrome P450 and glutathione $\mathrm{S}$-transferase genotypes as risk factors for multiple cutaneous basal cell carcinoma. Cancer Res 1996;56:1974-7.

33. Lear JT, Heagerty AH, Smith A, Bowers B, Payne CR, Smith CA, et al. Multiple cutaneous basal cell carcinomas: glutathione S-transferase (GSTM1, GSTT1) and cytochrome P450 (CYP2D6, CYP1A1) polymorphisms influence tumour numbers and accrual. Carcinogenesis 1996;17:1891-6.

34. Ramachandran S, Hoban PR, Ichii-Jones F, Pleasants L, AliOsman F, Lear JT, et al. Glutathione S-transferase GSTP1 and cyclin D1 genotypes: association with numbers of basal cell carcinomas in a patient subgroup at high-risk of multiple tumors. Pharmacogenetics 2000;10:545-56.

35. Cleaver JE. Ultraviolet photobiology: its early roots and insights into DNA repair. DNA Repair (Amst) 2002;1:977-9.

36. Segerbäck D, Strozyk M, Snellman E, Hemminki K. Repair of UV dimers in skin DNA of patients with basal cell carcinoma. Cancer Epidemiol Biomarkers Prev 2008; 17: 2388-92.

37. Yu CE, Oshima J, Fu YH, Wijsman EM, Hisama F, Alisch $\mathrm{R}$, et al. Positional cloning of the Werner's syndrome gene. Science 1996;272:258-62.

38. Ellis NA, Groden J, Ye TZ, Straughen J, Lennon DJ, Ciocci $S$, et al. The Bloom's syndrome gene product is homologous to RecQ helicases. Cell 1995;83:655-66.

39. Malkin D, Li FP, Strong LC, Fraumeni JF Jr, Nelson CE, Kim $\mathrm{DH}$, et al. Germ line p53 mutations in a familial syndrome of breast cancer, sarcomas, and other neoplasms. Science 1990;250:1233-8.

40. Vulliamy T, Marrone A, Goldman F, Dearlove A, Bessler $\mathrm{M}$, Mason PJ, et al. The RNA component of telomerase is mutated in autosomal dominant dyskeratosis congenita.
Nature 2001;413:432-5.

41. Wicking C, Smyth I, Bale A. The hedgehog signalling pathway in tumorigenesis and development. Oncogene 1999;18:7844-51.

42. Zibat A, Uhmann A, Nitzki F, Wijgerde M, Frommhold A, Heller T, et al. Time-point and dosage of gene inactivation determine the tumor spectrum in conditional $\mathrm{PTCH}$ knockouts. Carcinogenesis 2009;30:918-26.

43. Dicker T, Siller G, Saunders N. Molecular and cellular biology of basal cell carcinoma. Australas J Dermatol 2002;43:241-6.

44. Kovalenko A, Chable-Bessia C, Cantarella G, Israël A, Wallach $\mathrm{D}$, Courtois $\mathrm{G}$. The tumour suppressor CYLD negatively regulates NF-kappaB signalling by deubiquitination. Nature 2003;424:801-5.

45. Trompouki E, Hatzivassiliou E, Tsichritzis T, Farmer H, Ashworth A, Mosialos G. CYLD is a deubiquitinating enzyme that negatively regulates NF-kappaB activation by TNFR family members. Nature 2003;424:793-6.

46. Kastan MB, Onyekwere O, Sidransky D, Vogelstein B, Craig RW. Participation of $\mathrm{p} 53$ protein in the cellular response to DNA damage. Cancer Res 1991;51(23 Pt 1):6304-11.

47. Ronen D, Schwartz D, Teitz Y, Goldfinger N, Rotter V. Induction of HL-60 cells to undergo poptosis is determined by high levels of wild-type $\mathrm{p} 53$ protein whereas differentiation of the cells is mediated by lower p53 levels. Cell Growth Differ 1996;7: 21-30.

48. Hall PA, McKee PH, Menage HD, Dover R, Lane DP. High levels of $\mathrm{p} 53$ protein in UV-irradiated normal human skin. Oncogene 1993;8:203-7.

49. Auepemkiate S, Boonyaphiphat P, Thongsuksai P. P53 expression related to the aggressive infiltrative histopathological feature of basal cell carcinoma. Histopathology 2002;40: 568-73.

50. Rosenstein BS, Phelps RG, Weinstock MA, Bernstein JL, Gordon ML, Rudikoff D, et al. p53 mutations in basal cell carcinomas arising in routine users of sunscreens. Photochem Photobiol 1999;70:798-806.

51. Kim MY, Park HJ, Baek SC, Byun DG, Houh D. Mutations of the 553 and PTCH gene in basal cell carcinomas: UV mutation signature and strand bias. J Dermatol Sci 2002;29:1-9.

52. Fukasawa K, Choi T, Kuriyama R, Rulong S, Vande Woude GF. Abnormal centrosome amplification in the absence of $\mathrm{p} 53$. Science 1996;271:1744-7.

53. Liefer KM, Koster MI, Wang XJ, Yang A, McKeon F, Roop DR. Down-regulation of p63 is required for epidermal UV-Binduced apoptosis. Cancer Res 2000;60:4016-20.

54. Rodriguez-Villanueva J, Colome MI, Brisbay S, McDonnell TJ. The expression and localization of bcl-2 protein in normal skin and in non-melanoma skin cancers. Pathol Res Pract 1995;191:391-8.

55. Verhaegh ME, Sanders CJ, Arends JW, Neumann HA. Expression of the apoptosis-suppressing protein $\mathrm{Bcl}-2$ in nonmelanoma skin cancer. Br J Dermatol 1995; 132: 740-4.

56. Poniecka AW, Alexis JB. An immunohistochemical study of basal cell carcinoma and trichoepithelioma. Am J Dermatopathol 1999;21:332-6.

57. Rossen K, Karabulut Thorup A, Hou-Jensen K, Krag Jacobsen G. BAX protein is not expressed by basal cell carcinomas. $\mathrm{Br} \mathrm{J}$ Dermatol 1998;139:472-4.

58. Alamartine E, Berthoux P, Mariat C, Cambazard F, Berthoux F. Interleukin-10 promoter polymorphisms and susceptibility to skin squamous cell carcinoma after renal transplantation. J 
Invest Dermatol 2003;120:99-103.

59. Grimbaldeston M, Pearce AL, Robertson BO, Coventry BJ, Marshman G, Finlay-Jones JJ, et al. Association between melanoma and dermal mast cell prevalence in sun-unexposed skin. Br J Dermatol 2004;150:895-903.

60. Grimbaldeston MA, Skov L, Finlay-Jones JJ, Hart PH. Increased dermal mast cell prevalence and susceptibility to development of basal cell carcinoma in humans. Methods 2002;28:90-6.

61. Grimbaldeston MA, Skov L, Finlay-Jones JJ, Hart PH. Squamous cell carcinoma is not associated with high dermal mast cell prevalence in humans. J Invest Dermatol 2002;119: 1204-6.

62. Ch`ng S, Wallis RA, Yuan L, Davis PF, Tan ST. Mast cells and cutaneous malignancies. Mod Pathol 2006;19:149-59.

63. Harizi H, Juzan M, Pitard V, Moreau JF, Gualde N. Cyclooxygenase-2-issued prostaglandin $\mathrm{E}_{2}$ enhances the production of endogenous IL-10, which down-regulates dendritic cell functions. J Immunol 2002;168:2255-63.

64. Aubin F. Mechanisms involved in ultraviolet light-induced immunosuppresion. Eur J Dermatol 2003;13:515-23.

65. Kripke ML. Ultraviolet radiation and immunology: something new under the sun-presidential address. Cancer Res 1994;54:6102-5.

66. Streilein JW. Sunlight and skin-associated lymphoid tissues (SALT): if UVB is the trigger and TNF alpha is its mediator, what is the message? J Invest Dermatol 1993;100:47S-52S.

67. Ratner D, Lowe L, Johnson TM, Fader DJ. Perineural spread of basal cell carcinomas treated with Mohs micrographic surgery. Cancer 2000;88:1605-13.

68. Granstein RD. Cytokines and photocarcinogenesis. Photochem Photobiol 1996;63:390-4.

69. Fortis C, Foppoli M, Gianotti L, Galli L, Citterio G, Consogno $\mathrm{G}$, et al. Increased interleukin-10 serum levels in patients with solid tumors. Cancer Lett 1996;104:1-5.

70. Franceschi S, Dal Maso L, Arniani S, Crosignani P, Vercelli M, Simonato L, et al. Risk of cancer other than Kaposi's sarcoma and non-Hodgkin's lymphoma in persons with AIDS in Italy. Cancer AIDS Registry Linkage Study. Br J Cancer 1998;78:966-70.

71. Sitz KV, Keppen M, Johnson DF. Metastatic basal cell carcinoma in acquired immunodeficiency syndrome-related complex. 1987;257:340-3.

72. Cabrera T, Garrido V, Concha A, Martín J, Esquivias J, Oliva MR, et al. HLA molecules in basal cell carcinoma of the skin. Immunobiology 1992;185:440-52.

73. Garcia-Plata D, Mozos E, Sierra MA, Peña J, Solana R. HLA expression in basal cell carcinomas. Invasion Metastasis 1991;11:166-73.

74. Bavinck JN, Bastiaens MT, Marugg ME, Beckers RC, Westendorp RG, Vermeer BJ, et al. Further evidence for an association of HLA-DR7 with basal cell carcinoma on the tropical island of Saba. Arch Dermatol 2000;136:1019-22.

75. Rompel R, Petres J, Kaupert K, Müller-Eckhardt G. HLA phenotypes and multiple basal cell carcinomas. Dermatology 1994;189:222-4.

76. Rompel R, Petres J, Kaupert K, Müeller-Eckhardt G. Human leukocyte antigens and multiple basal cell carcinomas. Recent Results Cancer Res 1995;139:297-302.

77. Czarnecki D, Lewis A, Nicholson I, Tait B, Nash C. HLA-DR1 is not a sign of poor prognosis for the development of multiple basal cell carcinomas. J Am Acad Dermatol 1992;26:717-9.

78. Lacour JP. Carcinogenesis of basal cell carcinomas: genetics and molecular mechanisms. Br J Dermatol 2002;146(Suppl 61):17-9.

79. Owens DM, Watt FM. Contribution of stem cells and differentiated cells to epidermal tumours. Nat Rev Cancer 2003;3:444-51.

80. Miller SJ, Sun TT, Lavker RM. Hair follicles, stem cells and skin cancer. J Invest Dermatol 1993;100:288S-94S.

81. Tumbar T, Guasch G, Greco V, Blanpain C, Lowry WE, Rendl M, et al. Defining the epithelial stem cell niche in skin. Science 2004;303:359-63.

82. Lee Y, Miller HL, Russell HR, Boyd K, Curran T, McKinnon PJ. Patched 2 modulates tumorigenesis in Patched1 heterozygous mice. Cancer Res 2006;66:6964-71.

83. Walsh N, Ackerman AB. Infundibulocystic basal cell carcinoma: a newly described variant. Mod Pathol 1990;3:599-608.

84. Gho CG, Braun JE, Tilli CM, Neumann HA, Ramaekers FC. Human follicular stem cells: their presence in plucked hair and follicular cell culture. Br J Dermatol 2004;150:860-8.

85. Miller SJ, Wei ZG, Wilson C, Dzubow L, Sun TT, Lavker RM. Mouse skin is particularly susceptible to tumor initiation during early anagen of the hair cycle: possible involvement of hair follicle stem cells. J Invest Dermatol 1993;101:591-4.

86. Bernemann TM, Podda M, Wolter M, Boehncke WH. Expression of the basal cell adhesion molecule (B-CAM) in normal and diseased human skin. J Cutan Pathol 2000;27:108-11.

87. Kanitakis J, Bourchany D, Faure M, Claudy A. Expression of the hair stem cell-specific keratin 15 in pilar tumors of the skin. Eur J Dermatol 1999;9:363-5.

88. Quinn AG, Perkins W. Non-melanoma skin cancer and other epidermal skin tumours. In: Burns T, Breathnach S, Cox N, Griffiths C, editors. Rook's textbook of dermatology. $6^{\text {th }}$ ed. Oxford: Blackwell Publishing Ltd; 2010. p. 52.1-48.

\section{Abbreviations}

BCC - basal cell carcinoma
SCC - squamous cell carcinoma
DNA - deoxyribonucleic acid
UV - ultraviolet
C $\rightarrow$ T - cytosine $\rightarrow$ thymine
IL - interleukin
TNF-a - tumor necrosis factor alpha
PTCH - patched
Gy - Gray
HPV - human papillomavirus
Bak - Bcl-2 Antagonist/Killer
GST - glutathione S-transferase
CYP - cytochrome P450
Smo - smoothened
NF- $\mathrm{B}$ - nuclear factor kappa-light-chain-
enhancer of activated B cells
NEMO - nuclear factor B essential modulator
CYLD - cylindromatosis
Bcl - basall cell lymphoma

(C) 2009 The Serbian Association of Dermatovenereologists 
MMP - matrix metalloproteinase

GM-CSF - granulocyte-macrophage colony-

stimulating factor

NGF - nerve grouth factor
AIDS - acquired immunodeficiency syndrome

HLA - human leukocyte antigen

MHC - major histocompatibility complex

B-CAM - basal cell adhesion molecule

\section{Etiopatogeneza bazocelularnog karcinoma}

\section{Sažetak}

Uvod: Bazocelularni karcinom (BCK) predstavlja najčešći karcinom kod pripadnika kavkaske rase. Uglavnom nastaje na koži koja je izložena sunčevim zracima i najčešće se manifestuje na glavi i vratu (80\%), trupu (15\%), a retko na rukama i nogama. Bazocelularni karcinom je dobar primer oboljenja koje nastaje uzajamnim delovanjem genetike i faktora okoline.

Ultravioletni zraci: Ultravioletno (UV) zračenje ima dve ključne uloge u razvoju BCK: izazivanje DNK oštećenja i imunosupresija. Različitim mehanizmima UVA i UVB zraci oštećuju DNK. Direktno UVB zraci oštećuju DNK praveći karakteristične citozin $\rightarrow$ timin, $(\mathrm{C} \rightarrow \mathrm{T})$ mutacije na dipirimidinskim mestima $\mathrm{i}$ $\mathrm{CC} \rightarrow \mathrm{TT}$, dok UVA zraci imaju 10000 puta manje mutageno dejstvo, ali su značajno više prisutni u prirodnom UV zračenju. Takođe, fotoni UVA zračenja imaju manju energiju od UVB zračenja i nemaju mogućnost izazivanja mutacija. Imunosupresiju UV zračenje indukuje smanjenjem antigen-prezentujuće sposobnosti, kao i produkcijom imunosupresivnih citokina kao što su interleukin 10 (IL-10) i faktor nekroze tumora alfa (TNF-a). Medijatori imunosupresije indukovane UV zračenjem su DNK i cis-urokanična kiselina. Nekoliko studija pokazalo je značajnu udruženost između nastanka BCK i izlaganja suncu tokom detinjstva i adolescencije, kao i visoku povezanost $s$ porodičnom anamnezom o prisustvu karcinoma kože.

Jonizujuće zračenje: Izlaganje jonizujućem zračenju tri puta povećava rizik za nastanak nemelanomskih karcinoma kože, a rizik je proporcionalan primljenoj dozi zračenja.

Hemijski karcinogeni - arsen, katran, psoralen, pesticidi - povećavaju rizik za nastanaknemelanomskih karcinoma kože, uglavnom skvamocelularnog karcinoma (SCK).

Genetska predispozicija: Glutation S-transferaza
(GST) deo je ćelijskog odbrambenog sistema usmeren protiv hemijskih produkata, produkovanih endogeno ili delovanjem faktora spoljne sredine. Postoji nekoliko polimorfizama članova GST familije kod kojih je prisutna insuficijentna detoksifikacija, koja povećava rizik za nastanak karcinoma, uključujući i nemelanomske karcinome kože. Citohrom P450 enzimi uključeni su u proces detoksifikacije fotosenzitivnih agenasa, čime su uključeni i u proces karcinogeneze BCK.

PTCH je tumorski supresorski gen koji je prvi put otkriven kod pacijenata s Gorlin-Golcovim (Gorlin-Goltz) sindromom. Abnormalna aktivacija ovog gena i njegovog puta vode različitim tipovima tumorogeneze: za formiranje BCK neophodna je homozigotna delecija PTCH gena.

Pokazalo se da su agresivniji tipovi BCK udruženi s povećanom ekspresijom p53 proteina, koja verovatno predstavlja mutiranu formu, ali ova tvrdnja nije sa sigurnošću potvrđena.

Stečene genetske izmene: Imajući u vidu ograničenu ulogu koju imaju oštećenja DNK i hromozomska nestabilnost u nastanku BCK, značaj mutacija p53 gena u BCK ostaje i dalje nepotvrđen.

Podaci o ulozi ostalih članova $\mathrm{Bcl}-2$ familije gena $\mathrm{u}$ nastanku BCK su oskudni, ostaje nejasno da li Bcl2 ima funkcionalnu ulogu u nastanku BCK ili samo odražava nivo genske ekspresije u matičnim ćelijama tumora.

Aktivnost Ras gena može biti rani događaj u razvoju nemelanomskih karcinoma kože, a aktivacija se često može naći kod osoba obolelih od BCK, aktinične keratoze i SCK na koži koja je izložena UV zracima. Imunski faktori: Ispitivanja su pokazala da faktor nekroze tumora - $\alpha$ (TNF- $\alpha$ ) predstavlja glavni medijator u UV indukovanoj lokalnoj imunosupresiji: mast-ćelije sadrže velike količine TNF- $\alpha$, koji se oslobađa posle aktivancije; nivo TNF- $\alpha$ povišen je 
u koži izloženoj UV zracima, pri čemu on menja morfologiju i funkciju Langerhansovih ćelija, glavnih antigen- prezentujućih ćelija u koži. $\mathrm{Na}$ životinjskom modelu, pokazano je da stepen lokalne imunosupresije, izazvane UVB zračenjem, zavisi od nivoa TNF- $\alpha$ u epidermisu posle ozračivanja UVB zracima. Utvrđeno je da histamin poreklom iz mast-ćelija ostvaruje lokalni imunosupresivni efekat tako što: stimuliše produkciju prostaglandina E2 iz keratinocita koji menja citokinski balans, favorizujući u odnosu na imunostimulatorni
IL-12, produkciju imunosupresivnog IL-10; histamin nakon vezivanja za $\mathrm{H} 2$ receptore povećava funkciju supresorskih T-limfocita koji oslobađaju velike količine IL-10 indukujući apoptozu antigen- prezentujućih ćelija. Sve ovo rezultuje zamenom imunskog odgovora zavisnog od T-helper 1 citokinskog profila u korist supresivnog imunskog odgovora zavisnog od T-helper 2 citokinskog profila, čime se inhibira sposobnost antigen-prezentujućih ćelija da indukuju antitumorsku aktivnost.

\section{Ključne reči}

Bazocelularni karcinom + etiologija + patologija + genetika; Imunosupresija; Ultravioletni zraci; Faktori rizika; Tumor supresorski geni; p53 geni; bcl-2 geni 